\title{
Atomic Force Microscopy and Anodic Voltammetry Characterization of a 49-Mer Diels-Alderase Ribozyme
}

\author{
A. M. Chiorcea-Paquim, ${ }^{\dagger}$ J. A. P. Piedade, ${ }^{\dagger}$ R. Wombacher, ${ }^{\ddagger}$ A. Jäschke, ${ }^{\ddagger}$ and A. M. Oliveira-Brett ${ }^{\star \star,}$ \\ Departamento de Química, Faculdade de Ciências e Tecnologia, Universidade de Coimbra, 3004-535 Coimbra, Portugal, \\ and Institut für Pharmazie und Molekulare Biotechnologie, Universität Heidelberg, D-69120, Heidelberg, Germany
}

Atomic force microscopy and differential pulse voltammetry were used to characterize the interaction of small highly structured ribozymes with two carbon electrode surfaces. The ribozymes spontaneously self-assemble in two-dimensional networks that cover the entire HOPG surface uniformly. The full-length ribozyme was adsorbed to a lesser extent than a truncated RNA sequence, presumably due to the formation of a more compact overall structure. All four nucleobases composing the ribozyme could be detected by anodic voltammetry on glassy carbon electrodes, and no signals corresponding to free nucleobases were found, indicating the integrity of the ribozyme molecules. $\mathrm{Mg}^{2+}$ cations significantly reduced the adsorption of ribozymes to the surfaces, in agreement with the stabilization of this ribozyme's compact, stable, and tightly folded tertiary structure by $\mathrm{Mg}^{2+}$ ions that could prevent the hydrophobic bases from interacting with the HOPG surface. Treatment with $\mathrm{Pb}^{2+}$ ions, on the other hand, resulted in an increased adsorption of the RNA due to well-known hydrolytic cleavage. The observed dependence of anodic peak currents on different folding states of RNA may provide an attractive method to electrochemically monitor structural changes associated with RNA folding, binding, and catalysis.

One of the most fascinating features of RNA molecules is their ability to catalyze chemical reactions. The mechanisms by which these so-called ribozymes accelerate chemical reactions have received much attention over the past two decades. ${ }^{1-4}$ In vitro selection and evolution experiments have demonstrated that ribozymes are able to accelerate a much broader range of chemical reactions than just hydrolysis and transesterification of internucleotide bonds, the first types of catalytic activity attributed to RNA. ${ }^{5-9}$

* To whom correspondence should be addressed. Tel/FAX: +351-239-835295. E-mail: brett@ci.uc.pt.

$\dagger$ Universidade de Coimbra.

* Universität Heidelberg

(1) Kruger, K.; Grabowski, P. J.; Zaug, A. J.; Sands, J.; Gottschling, D. E.; Cech, T. R. Cell 1982, 31, 145-157.

(2) Guerrier-Takada, C.; Gardiner, K.; Marsh, T.; Pace, N.; Altman, S. Cell 1983, 35, 849-857.

(3) Cech, T. R. Biochem. Soc. Trans. 2002, 30, 1162-1166.

(4) Jäschke, A. Curr. Opin. Chem. Biol. 2001, 11, 321-326.

(5) Doudna, J. A.; Cech, T. R. Nature 2002, 418, 222-228.

(6) Jäschke, A.; Seelig, B. Curr. Opin. Chem. Biol. 2000, 4, 257-262.
This chemical versatility not only demonstrates RNA's power as a catalyst but also hints at RNA's capacities in the context of a hypothetic RNA world that may have preceded today's proteindominated life. ${ }^{10}$

The most thoroughly characterized artificial ribozymes accelerate the formation of carbon-carbon bonds by Diels-Alder reaction, a [4+2] cycloaddition reaction between anthracene dienes and maleimide dienophiles. ${ }^{11-15}$ The secondary and tertiary structures of a 49-mer Diels-Alderase ribozyme have been elucidated (Figure 1), and its interactions with the substrates and products were studied. ${ }^{13-16}$

Metal cations are essential for RNA folding and catalytic activity, and there has been considerable effort to understand how metal ions interact with RNA molecules. ${ }^{17-21} \mathrm{Mg}^{2+}$ is very effective in the stabilization of RNA tertiary structures and, consequently, plays an important part in catalysis, too. ${ }^{18-22}$ Lead ions, on the other hand, induce hydrolysis of RNA molecules in a structuredependent manner. ${ }^{23,24}$ For the Diels-Alderase ribozyme, a crucial role of $\mathrm{Mg}^{2+}$ in the stabilization of the tertiary structure was observed, ${ }^{14}$ whereas $\mathrm{Pb}^{2+}$ was found to induce strong cleavage of the hexanucleotide stretch in the asymmetric internal loop (Figure 1). Increasing concentrations of $\mathrm{Mg}^{2+}$ ions in solution were shown to diminish the $\mathrm{Pb}^{2+}$ cleavage effect. ${ }^{13}$

(7) Hausch, F.; Jäschke, A. Bioconjugate. Chem. 1997, 8, 885-890.

(8) Mandal, M.; Breaker, R. R. Nature Rev. Mol. Cell Biol. 2004, 5, 451-463.

(9) Nudler, E.; Mironov, A. S. Trends Biochem. Sci. 2001, 26, 699-701.

(10) Murray, J. M.; Doudna, J. A. Trends Biochem. Sci. 2001, 26, 699-701.

(11) Seelig, B.; Jäschke, A. Chem. Biol. 1999, 6, 167-176.

(12) Tarasow, T. M.; Tarasow, S. L.; Eaton, B. E. Nature 1997, 389, 54-57.

(13) Keiper, S.; Bebenroth, D.; Seelig, B.; Westhof, E.; Jäschke, A. Chem. Biol. 2004, 11, 1217-1227.

(14) Serganov, A.; Keiper, S.; Malinina, L.; Tereshko, V.; Skripkin, E.; Höbartner, C.; Polonskaia, A.; Phan, A. T.; Wombacher, R.; Micura, R.; Dauter, Z.; Jäschke, A.; Patel, D. J. Nat. Struct. Mol. Biol. 2005, 12, 218-224.

(15) Helm, M.; Petermeier, M.; Ge, B.; Fiammengo, R.; Jäschke, A. J. Am. Chem. Soc. 2005, 127, 10942-10493.

(16) Stuhlmann, F.; Jäschke, A. J. Am. Chem. Soc. 2002, 124, 3238-3244

(17) Woodson, S. A. Curr. Opin. Chem. Biol. 2005, 9, 104-109.

(18) Fedor, M. J. Curr. Opin. Struct. Biol. 2002, 12, 289-295.

(19) DeRose, V. J. Curr. Opin. Struct. Biol. 2003, 13, 317-324.

(20) Pyle, A. M. J. Biol. Inorg. Chem. 2002, 7, 679-690.

(21) Draper, D. E. RNA 2004, 10, 335-343.

(22) Misra, V. K.; Draper, D. E. Proc. Nat. Acad. Sci. USA. 2001, 23, 1245612461.

(23) Brown, R. S.; Dewan, J. C.; Klug, A. Biochemistry 1985, 24, 4785-4801.

(24) Behlen, L. S.; Sampson, J. R.; Direnzo, A. B.; Uhlenbeck, O. C. Biochemistry 1991, 29, 2515-2523. 

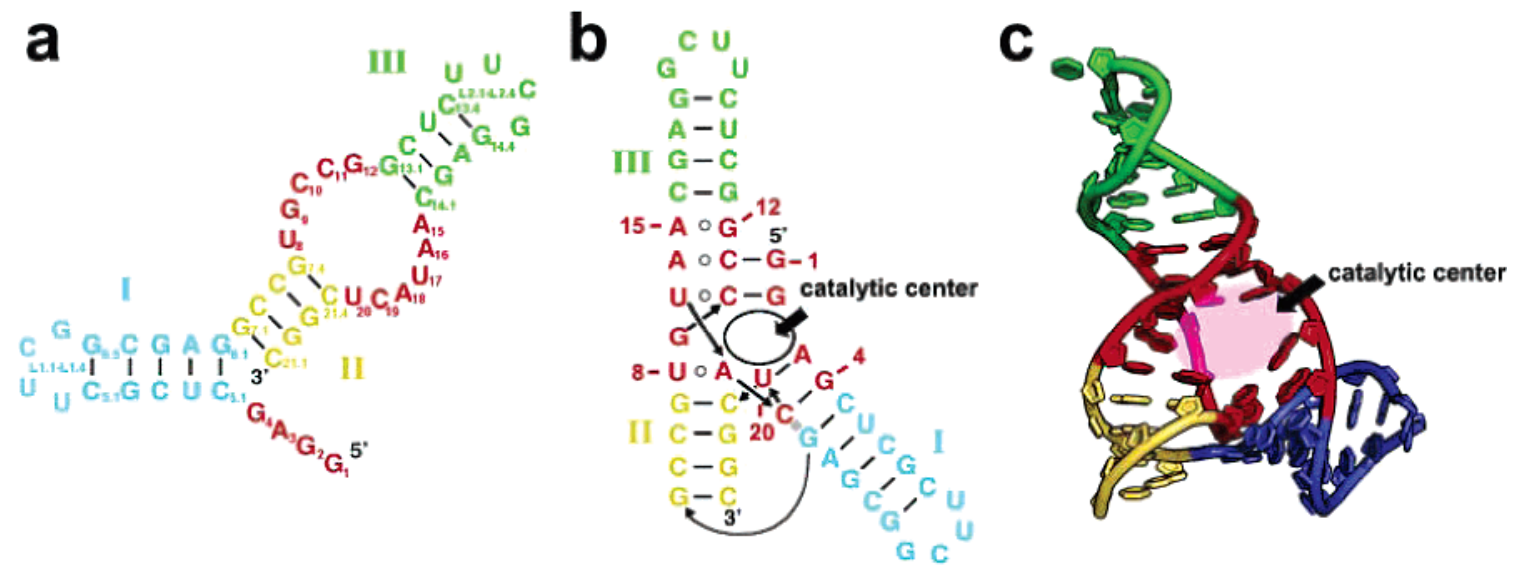

Figure 1. Secondary and tertiary folds of the Diels-Alderase ribozyme. (a) 49-Mer ribozyme secondary structure with stems I-III in cyan, gold, and green, respectively, and formally single-stranded regions in red. (b, c) Tertiary fold (b) and three-dimensional topology (c) in the crystal structure of the ribozyme-product complex. The crystal structure is from a bipartite 38- and 11-mer complex.

Atomic force microscopy (AFM) can give important information about the adsorption and morphological characteristics of biological compounds on solid surfaces. AFM can visualize individual DNA or RNA molecules and DNA-protein complexes immobilized onto mica or silicon in air and in solution, with extraordinary resolution and accuracy. ${ }^{25-31}$ However, AFM has preferentially been used to observe large RNA molecules, ${ }^{28,29}$ and only a few studies report the investigation of small RNA sequences. ${ }^{32}$ Small single-stranded DNA and small DNA duplexes (up to $50 \mathrm{bp}$ ) yield images of globular shape, while longer DNA molecules (100 bp and higher) appear rodlike or slightly curved. ${ }^{27,33}$

Voltammetric methods permit the detection of the individual nucleobases, nucleosides, and nucleotides contained in nucleic acids and, furthermore, allow us to distinguish between singlestranded and double-stranded nucleic acids in an inexpensive and fast assay. ${ }^{34}$ This distinction is based on the fact that, in doublestranded nucleic acid, bases are less accessible than in single stranded to be oxidized at the electrode surface once they are hindered inside the helix. Furthermore, free bases oxidize at less positive potentials than their corresponding nucleotides, and wellseparated voltammetric signals can be detected allowing the characterization of the nucleic acid sample. RNA could be distinguished from double- and single-stranded DNA based on cathodic cyclic voltammetry signals using a mercury electrode ${ }^{35,36}$

(25) Hansma, H. G.; Kasuya, K.; Oroudjev, E. Curr. Opin. Struct. Biol. 2004, 14, 380-385.

(26) Engel, A.; Lyubchenko, Y.; Müller, D. Cell Biol. 1999, 9, 77-80.

(27) Hansma, H. G.; Revenko, I.; Kim, K.; Laney, D. E. Nucleic Acids Res. 1996, 24, 713-720.

(28) Bonin, M.; Oberstrass, J.; Lukacs, N.; Ewert, K.; Oesterschulze, E.; Kassing, R.; Nellen, W. RNA 2000, 6, 563-570.

(29) Hansma, H. G.; Golan, R.; Hsieh, W.; Daubendiek, S. L.; Kool, E. T. J. Struct. Biol. 1999, 127, 240-247.

(30) Hansma, H. G.; Oroudjed, E.; Baudrey, S.; Jaeger, L. J. Microsc. 2003, 212, 273-279.

(31) Chworos, A.; Severcan, I.; Koyfman, A. Y.; Weinkam, P.; Oroudjev, E.; Hansma, H. G.; Jaeger, L. Science 2004, 306, 2068-2072.

(32) Fay, M. J.; Walter, N. G.; Burke, J. M. RNA 2001, 7, 887-895.

(33) Chiorcea, Paquim, A.-M.; Oretskaya, T. S.; Oliveira, Brett, A. M. Biophys. Chem. 2006, 121, 131-141.

(34) Oliveira-Brett, A. M.; Piedade, J. A. P.; Silva, L. A.; Diculescu, V. C. Anal. Biochem. 2004, 332, 321-329.

(35) Fojta, M.; Teijeiro, C.; Palecek, E. Bioelectrochem. Bioenerg. 1994, 34, 69 76.

(36) Brabec, V.; Palecek, E. Biophys. Chem. 1976, 4, 79-92. and the electrochemical oxidation of denatured DNA and ribosomal and transfer RNA at a pyrolytic graphite electrode has been studied. ${ }^{37}$ Recently, we could demonstrate the detection of uracil and related compounds using carbon electrodes, allowing a better distinction between DNA and RNA by voltammetric techniques..$^{38}$

In this context, the principal objective of the present work was to investigate by magnetic AC mode AFM (MAC Mode AFM) imaging and differential pulse voltammetry how small, highly structured RNAs interact with carbon electrode surfaces and how structural changes influence this interaction. A free adsorption study of the ribozymes was performed on a highly oriented pyrolytic graphite (HOPG) electrode. HOPG was selected as electrode material since it is extremely smooth, inert in air, and easy to clean, which is an important requirement for imaging biological molecules, compared with the irregular rough surface of glassy carbon (GC) electrodes ${ }^{39,40}$ that has been used in the electrochemical assays. The investigation of the interactions of the 49-mer Diels-Alderase ribozyme with electrode materials and their dependence on $\mathrm{Mg}^{2+}$ and $\mathrm{Pb}^{2+}$ ion concentrations described here provides the first information about the behavior of small highly structured RNA on carbon electrode surfaces.

\section{EXPERIMENTAL PROCEDURES}

Materials. Homopolyribonucleotides poly[Guo], poly[Ado], poly[Urd], and poly[Cyd] sodium salts were all obtained from Sigma-Aldrich (Sigma-Aldrich Chemie Gmbh, Steinheim, Germany) and used without further purification. 38-Mer RNA and 49mer Diels-Alderase ribozymes, Figure 1, were synthesized as described. ${ }^{11}$

The electrolyte used was $\mathrm{pH}$ 7.1, $0.05 \mathrm{M}$ phosphate buffer solution and was prepared using analytical grade reagents and purified water from a Millipore Milli-Q system (conductivity $<0.1$ $\mu \mathrm{S} \mathrm{cm}^{-1}$ ) filtered through a $0.2 \mu \mathrm{m}$ sterile porous membrane. Solutions of different concentrations were prepared by direct dilution of the appropriate volume in phosphate buffer and in

(37) Brabec, V.; Dryhurst, G. J. Electroanal. Chem. 1978, 89, 161-173.

(38) Goyal, R. N.; Singh, U. P.; Abdullah, A. A. Indian J. Chem. 2003, 42A, 4247.

(39) Oliveira, Brett, A. M.; Chiorcea, A.-M. Langmuir 2003, 19, 3830-3839.

(40) Oliveira, Brett, A. M.; Chiorcea, A.-M. Bioelectrochemistry 2004, 63, 229 232. 
Milli-Q water. Stock and diluted RNA solutions in $\mathrm{pH} 7.1,0.05 \mathrm{M}$ phosphate buffer and water were kept frozen at $-20{ }^{\circ} \mathrm{C}$ until the $\mathrm{AFM}$ and voltammetric experiments were performed.

Nano and microvolumes were measured using a EP-10 Plus and a EP-100 Plus Motorized Microliter Pipet (Rainin Instrument Co. Inc.). The $\mathrm{pH}$ was measured with a Crison model MicropH $2001 \mathrm{pH}-\mathrm{meter}$ (Crison Instruments, Barcelona, Spain) with an Ingold combined glass electrode. All experiments were done at room temperature $\left(25 \pm 1{ }^{\circ} \mathrm{C}\right)$.

Atomic Force Microscopy. AFM was performed with a PicoSPM controlled by a MAC Mode module and interfaced with a PicoScan controller (Molecular Imaging Corp., Tempe, AZ). All AFM experiments were performed with a CS AFM S scanner with a scan range of $6 \mu \mathrm{m}$ in $x-y$ and $2 \mu \mathrm{m}$ in $z$ (Molecular Imaging Corp.). Silicon type II MAClevers of $225 \mu \mathrm{m}$ length, tip radius of curvature less than $10 \mathrm{~nm}, 2.8 \mathrm{~N} \mathrm{~m}^{-1}$ spring constant, and 60-90 $\mathrm{kHz}$ resonant frequencies in air (Molecular Imaging Corp.) were used in MAC Mode AFM. All images (256 samples line ${ }^{-1} \times 256$ lines) were taken at room temperature, with scan rates of 1.0 2.5 lines $\mathrm{s}^{-1}$. The images were processed by flattening in order to remove the background slope, and the contrast and brightness were adjusted.

All images were visualized in three dimensions using the demo version 3.2.3.0 Scanning Probe Image Processor (SPIP; Image Metrology ApS). Section analysis over the molecules and films was performed with PicoScan software version 5.3.1 (Molecular Imaging Co.) and with Origin version 6.0 (Microcal Software, Inc.). Origin version 6.0 was used to calculate the mean values of the heights and standard deviation and all the experimental height/ thickness distribution graphs.

HOPG, grade ZYB, of rectangular shape with $15 \times 15 \times 2$ mm dimensions (Advanced Ceramics Co.) was used throughout the AFM study as a substrate. The HOPG was freshly cleaved with adhesive tape prior to each experiment and was imaged by AFM in order to establish its cleanliness.

The RNA samples were prepared by free adsorption. $100 \mu \mathrm{L}$ samples of different concentrations of RNA solutions were deposited onto freshly cleaved HOPG surfaces and incubated for $3 \mathrm{~min}$. The excess of molecules was gently cleaned with a jet of Millipore Milli-Q water, and the HOPG with adsorbed RNA was then dried with nitrogen.

To study the influence of $\mathrm{Mg}^{2+}$ and $\mathrm{Pb}^{2+}$ ions on the ribozyme structure, 49-mer ribozymes were freshly dissolved in $0.05 \mathrm{M}$ phosphate buffer solutions ( $\mathrm{pH}$ 7.1) or Milli-Q water containing $\mathrm{MgCl}_{2}$ and $\mathrm{Pb}\left(\mathrm{NO}_{3}\right)_{2}$, respectively. The ribozyme solutions containing $\mathrm{MgCl}_{2}$ or $\mathrm{Pb}\left(\mathrm{NO}_{3}\right)_{2}$ were used after $1 \mathrm{~h}$ and $30 \mathrm{~min}$ incubation time. The $100 \mu \mathrm{L}$ samples were deposited onto freshly cleaved HOPG surfaces and incubated for $3 \mathrm{~min}$. The excess of molecules was gently cleaned with a jet of Millipore Milli-Q water, and the HOPG with adsorbed ribozymes was then dried with nitrogen.

Electrochemical Conditions. All voltammetric experiments were performed by using a $\mu$ Autolab Type II with GPES version 4.9 software (Eco-Chemie, Utrecht, The Netherlands). A onecompartment electrochemical cell with a volumetric capacity of $100 \mu \mathrm{L}$ was used, containing a GC working electrode of diameter $1.5 \mathrm{~mm}$ (Cypress Systems), a Pt wire counter electrode, and an $\mathrm{Ag} / \mathrm{AgCl}$ reference electrode ( $3 \mathrm{M} \mathrm{KCl}$ saturated with $\mathrm{AgCl})$. The cell was placed inside a Faraday cage, and all experiments were carried out at constant room temperature during all the measurements.

The differential pulse voltammetric parameters used, unless otherwise stated, were as follows: pulse amplitude $50 \mathrm{mV}$, pulse width $70 \mathrm{~ms}$, scan rate $5 \mathrm{mV} \mathrm{s}^{-1}$, and equilibration time $10 \mathrm{~s}$. All potentials are referred to the $\mathrm{Ag} / \mathrm{AgCl}$ reference electrode.

The glassy carbon electrode was polished using alumina of particle size $0.3 \mu \mathrm{m}$ before every electrochemical assay. After polishing, the electrode was rinsed thoroughly with Milli-Q water during $30 \mathrm{~s}$; the electrode was sonicated for $1 \mathrm{~min}$ in an ultrasound bath and again rinsed with water. After this mechanical treatment, electrochemical preconditioning was carried out in three steps: first, the potential of the electrode was scanned between +0.30 and $+1.50 \mathrm{~V}$, at $5 \mathrm{mV} \mathrm{s}^{-1}$, in phosphate buffer solution to check the cleanliness of the electrode surface; second, a $+1.75 \mathrm{~V}$ potential was applied for $300 \mathrm{~s}$; finally, the electrode was successively cycled between +0.30 and $+1.70 \mathrm{~V}$ in a new phosphate buffer electrolyte solution, until a steady-state baseline voltammogram was obtained. This procedure ensured very reproducible experimental results.

All experimental curves presented were background-subtracted and baseline-corrected using the moving average application with a step window of $5 \mathrm{mV}$ included in GPES version 4.9 software. This mathematical treatment improves the visualization and identification of peaks over the baseline without introducing any artifact, although the peak intensity is in some cases reduced $(<10 \%)$ relative to that of the untreated curve. Nevertheless, this mathematical treatment of the original voltammograms was used in the presentation of all experimental voltammograms for a better and clearer identification of the peaks.

The values for peak current and charge presented in all graphs, however, were determined from the original untreated voltammograms.

To study the influence of the $\mathrm{Mg}^{2+}$ and $\mathrm{Pb}^{2+}$ cations, a solution of $50 \mu \mathrm{g} \mathrm{mL} \mathrm{m}^{-1}$ of 49 -mer RNA in $\mathrm{pH} 7.1,0.05 \mathrm{M}$ phosphate buffer was incubated for $30 \mathrm{~min}$ with increasing concentrations of each cation in the presence and absence of a constant concentration of the other salt (100 $\mu \mathrm{M} \mathrm{MgCl}_{2}$ or $\left.50 \mu \mathrm{M} \mathrm{Pb}\left(\mathrm{NO}_{3}\right)_{2}\right)$, prior to the voltammetric scan.

\section{RESULTS AND DISCUSSION}

Atomic Force Microscopy Characterization of 49-Mer Diels-Alderase Ribozyme. The adsorption of 49-mer DielsAlderase ribozymes and 38-mer RNA sequences on electrode surfaces was investigated. The 38-mer sequence is derived from the ribozyme but lacks the 5 -terminal nucleotides essential for the formation of the tertiary structure. The modification of the electrode was performed by free adsorption from solution of concentrations of $1,5,10$, and $18 \mu \mathrm{g} \mathrm{mL}-1$, as described in Experimental Procedures, and the RNA-modified surfaces were then characterized using AFM in air.

RNA is a highly charged, hydrophilic molecule, whereas HOPG has a hydrophobic surface. These characteristics reduce the spontaneous interaction of RNA with the HOPG surface. Despite the fact that MAC Mode AFM is a gentle technique, with a view to minimizing as much as possible any damage to the biological films by the AFM tip, it represents one of the most significant problems when imaging nucleic acid molecules. In order to 

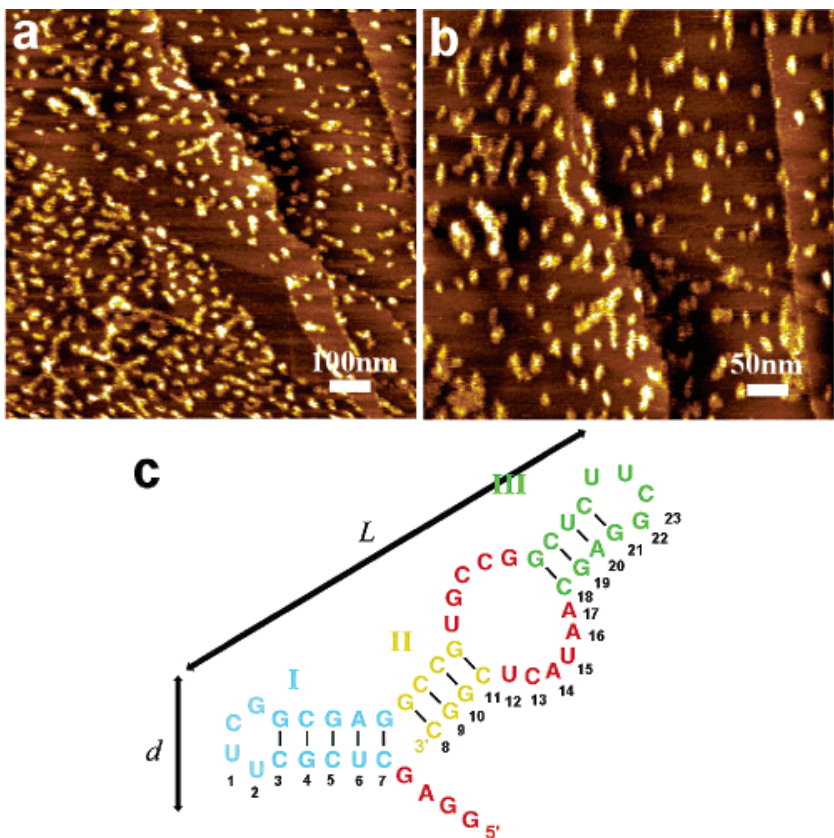

Figure 2. (a, b)AFM topographical images in air of 49-mer ribozyme molecules, immobilized by free adsorption during 3 min onto HOPG, from $1 \mu \mathrm{g} \mathrm{mL}^{-1}$ ribozymes in $\mathrm{pH} 7.1,0.05 \mathrm{M}$ phosphate buffer. (c) Ribozyme secondary structure with representation of the estimated ribozyme average dimensions: the width $d$ larger than the helix diameter of a base pair and the average length $L$ taking into consideration the effective contribution of $\sim 23$ base and base pairs.

improve the stability of the molecules on the surface, the 49-mer Diels-Alderase ribozymes and 38-mer RNA were dried before being observed by AFM.

In all AFM experiments, HOPG was used as substrate. The extremely smooth, inert in air, and easy to clean terraces of the HOPG electrode basal plane are an important advantage in studying adsorbed biological molecules. While the glassy carbon presents a root-mean-square $(\mathrm{rms})$ roughness of $2.10 \mathrm{~nm}$, the HOPG electrode surface has an rms roughness of less than 0.06 $\mathrm{nm}$, for a $1000 \times 1000 \mathrm{~nm}^{2}$ surface area. ${ }^{39,40}$

Free adsorption from a low concentration of $1 \mu \mathrm{g} \mathrm{mL}-1$ demonstrated that the 49-mer ribozymes adsorb readily onto HOPG. Bright areas appear in the AFM images, showing bloblike features that can be related with individual ribozymes molecules (Figure 2a and b). The average height and standard deviation of the rodlike aggregates was $1.5 \pm 0.3 \mathrm{~nm}$. Increasing the concentration from 1 to $5 \mu \mathrm{g} \mathrm{mL}{ }^{-1}$, the AFM images showed the formation of a noncompact thin network (Figure 3a). The small ribozymes adsorb onto the HOPG surface next to each other, forming looped filaments with large portions of uncovered HOPG surface-the dark regions in the images. The measured thickness of the film was $1.5 \pm 0.3 \mathrm{~nm}$. At $10 \mu \mathrm{g} \mathrm{mL} \mathrm{m}^{-1}$, the ribozyme film became more compact, and more extended areas of the HOPG surface were covered by molecules (Figure 3c). However, the film had many pores, with exposed HOPG surface at the bottom of the pores. The surface of the film was smooth with a height of $1.45 \pm 0.3 \mathrm{~nm}$. When concentrations of $18 \mu \mathrm{g} \mathrm{mL}^{-1}$ were used, the ribozymes formed a thick film that completely covered the HOPG electrode (Figure 3e). The topography of the film showed nuclei of different sizes from 2 to $30 \mathrm{~nm}$ height.
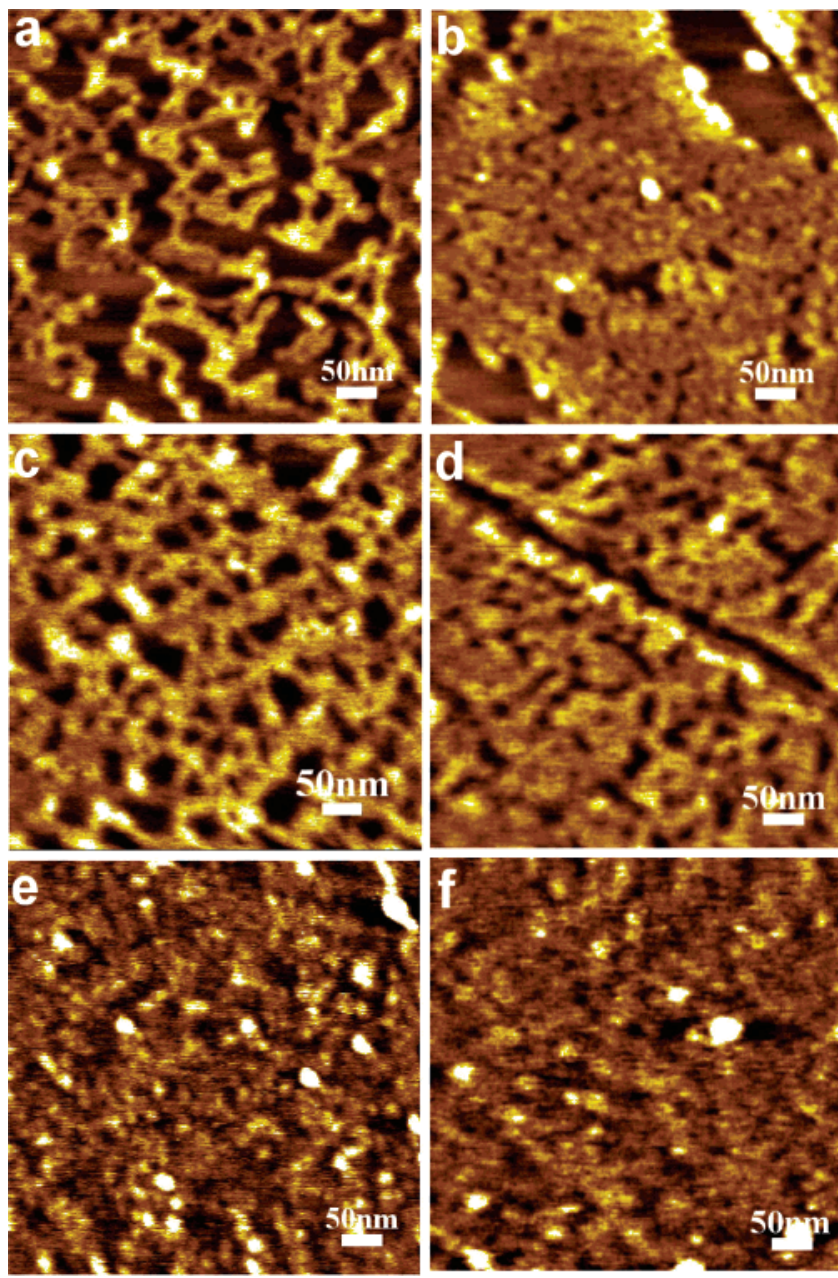

Figure 3. AFM topographical images in air of (a, c, e) 49-me ribozyme and (b, d, f) 38-mer RNA molecules, immobilized by free adsorption during 3 min onto HOPG, from the following: (a, b) 5, (c, d) 10 , and (e, f) $18 \mu \mathrm{g} \mathrm{mL}^{-1}$ in $\mathrm{pH} 7.10 .05 \mathrm{M}$ phosphate buffer.

In order to depict the influence of different structural features on the adsorption process of the Diels-Alderase ribozyme onto HOPG, the adsorption of the 49-mer ribozyme was compared with the adsorption of the 38-mer truncated RNA sequence that lacks the $5^{\prime}$-end and folds into a different structure in buffered solution. As observed in the AFM images, the 38-mer RNA sequences adsorb more strongly onto HOPG, leading to an increased surface coverage, when compared with the 49-mer ribozymes for the same solution concentration (Figure $3 \mathrm{~b}, \mathrm{~d}$, and e). This is presumably due to the fact that the 38-mer RNA presents a less compact and tightly folded architecture, and the hydrophobic bases are less protected inside the secondary structure, suggesting that the 49mer ribozymes adsorb onto HOPG with a more compact structure.

The geometric parameters of the AFM tip represent a limiting factor in the high-resolution investigation of biological materials. For such small molecules, the AFM-measured width is usually much larger than the real width or length of the molecule, due to the convolution effect of the tip radius. The 49-mer ribozyme molecules adsorbed to the HOPG surface are very small. Generally, for an RNA molecule, the helix diameter of a base pair can be considered as $\sim 2.0 \mathrm{~nm}$ and the average axial rise per base or base pair as $\sim 0.3 \mathrm{~nm}$. The full-length ribozyme adopts a defined architecture, ${ }^{13,14}$ with secondary and tertiary structures. The 
secondary structure is formed by three double-helical stems, an asymmetric internal loop composed of a pentanucleotide, UGCCA, and a hexanucleotide, AAUACU, and a formally single-stranded 5'-terminal GGAG tetranucleotide (Figure 1a). The tertiary structure is based on additional base interactions between the four $5^{\prime}$ terminal bases and bases at both sides of the internal loop, involving base pairing between $\mathrm{A}_{3}$ and $\mathrm{G}_{4}$ at the $5^{\prime}$-end and $\mathrm{U}_{20}$ and $\mathrm{C}_{19}$ on the longer side, and between $\mathrm{G}_{1}$ and $\mathrm{G}_{2}$ at the $5^{\prime}$-end and $\mathrm{C}_{11}$ and $\mathrm{C}_{10}$ on the shorter side of the internal loop (Figure $1 \mathrm{~b}$ and $\mathrm{c}$ ). The dimensions of the completely folded $\lambda$-shaped ribozyme measured in the crystal structure are $\sim 6.1 \mathrm{~nm}$ (length) $\times 4.2 \mathrm{~nm}$ (width at the base of the " $\lambda$ ") $\times 2.0 \mathrm{~nm}$ (height).

The formation of the tertiary structure, however, requires the presence of $\mathrm{Mg}^{2+}$ ions, which were not present in this set of experiments. Therefore, only the secondary structure will be considered, and the average dimensions can be estimated as follows: the width $d$ will be larger than the helix diameter of a base pair of $\sim 2.0 \mathrm{~nm}$, and the average length $L$ of $\sim 6.9 \mathrm{~nm}$, considering that only $\sim 23$ bases contribute to the ribozyme length (Figure 2c). Rough estimates of the AFM-measured dimensions of adsorbed molecules can be obtained using a simplified model of a spherical tip in contact with a small, well-defined, incompressible, spherical molecule. In the case of an AFM tip with spherical geometry, the measured width $l$ of a molecule with molecular radius $r$ depends on the AFM tip radius $R$ according to the formula $l=4(R r)^{1 / 2}{ }^{41}$ For a tip radius of $\sim 10 \mathrm{~nm}$, we expect to observe an apparent ribozyme width $d$ larger than $12.6 \mathrm{~nm}$ in the AFM images and an apparent length $L$ of $\sim 23.5 \mathrm{~nm}$. As a result, a single ribozyme molecule will appear in the AFM images with a rodlike shape, with overestimated helix diameter and apparent length, due to the convolution effect of the AFM tip radius of curvature.

Indeed, the small 49-mer ribozyme molecules appear in the AFM images as rod-like aggregates with a measured full width at half-maximum height (fwhm) of $\sim 10-30 \mathrm{~nm}$. However, since the tip makes a major contribution to the measured width, it is not possible to distinguish between mono- and bimolecular aggregates on the surface.

Compared to the fwhm measurements, the height (z-dimension) gives a better representation of the ribozyme dimensions, since it is not limited by the tip radius of curvature. In AFM studies in air, the reported heights for DNA and RNA attached to a solid substrate vary from 0.5 to $1.9 \mathrm{~nm},{ }^{27}$ with the difference between the true height and the measured one being attributed to elastic deformations to the molecules caused by the AFM tip. Consequently we conclude that the measured heights of $\sim 1.5 \mathrm{~nm}$ of the rodlike aggregates correspond to a monolayer of molecules.

Voltammetric Determination of 49-Mer Diels-Alderase Ribozyme. The voltammetric behavior of four polyhomoribonucleotides was previously studied to enable the identification of the electrochemical properties of DNA and RNA molecules. ${ }^{34}$ It could be shown that pyrimidine nucleotides undergo oxidation at higher potentials close to the potential corresponding to oxidation of the electrolyte. More concentrated pyrimidine solutions had to be used to obtain current peaks of the same order of

(41) Zenhausern, F.; Adrian, M.; Emch, R.; Taborelli, M.; Jobin, M.; Descouts, P. Ultramicroscopy 1992, 42-44, 1168-1172.

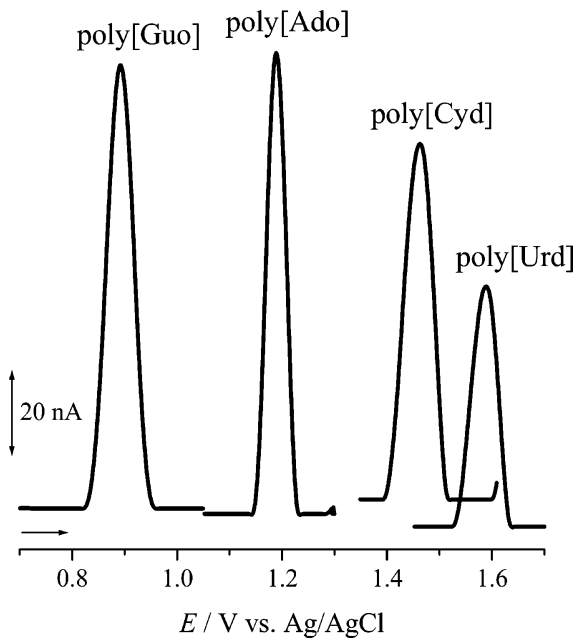

Figure 4. Baseline-corrected differential pulse voltammograms in $\mathrm{pH} 7.1,0.05 \mathrm{M}$ phosphate buffer supporting electrolyte for the following: $40 \mu \mathrm{g} \mathrm{mL}^{-1}$ poly[Guo] and poly[Ado], $100 \mu \mathrm{g} \mathrm{mL}^{-1}$ poly[Cyd], and $250 \mu \mathrm{g} \mathrm{mL}^{-1}$ poly[Urd]. Pulse amplitude $50 \mathrm{mV}$, pulse width $70 \mathrm{~ms}$, and scan rate $5 \mathrm{mV} \mathrm{s}^{-1}$.

magnitude as those of the purine polynucleotides, which undergo oxidation at less positive potentials. ${ }^{34}$

The differential pulse voltammograms obtained for $40 \mu \mathrm{g} \mathrm{mL}-1$ poly[Guo] and poly[Ado], $100 \mu \mathrm{g} \mathrm{mL}^{-1}$ poly[Cyd], and $250 \mu \mathrm{g}$ $\mathrm{mL}^{-1}$ poly[Urd] in $0.05 \mathrm{M}$ phosphate buffer $\mathrm{pH} 7.1$ supporting electrolyte are shown in Figure 4. One current peak is observed for each polyhomoribonucleotide: a peak at $+0.89 \mathrm{~V}$ attributed to the oxidation of guanine residue (Guo) in poly[Guo], a peak at $+1.19 \mathrm{~V}$ due to the oxidation of adenine residue (Ado) was detected in poly[Ado] solutions, a peak at $+1.46 \mathrm{~V}$ attributed to the oxidation of cytosine residue (Cyd) was observed for poly[Cyd], and a peak at $+1.58 \mathrm{~V}$ attributed to the oxidation of uracil residue (Urd) was detected in poly[Urd].

Voltammetric experiments using 49- and 38-mer RNA were carried out with concentrations of $50 \mu \mathrm{g} \mathrm{mL}$, in order to guarantee complete ribozyme coverage of the carbon electrode surface (Figure 3e).

Figure 5 shows a differential pulse voltammogram obtained for $50 \mu \mathrm{g} \mathrm{mL} \mathrm{m}^{-1} 49$-mer RNA. Four peaks appear: at $+0.92 \mathrm{~V}$, attributed to the oxidation of guanine residue (Guo), at $+1.15 \mathrm{~V}$ to the oxidation of adenine residue (Ado), at $+1.39 \mathrm{~V}$ attributed to the oxidation of cytosine residue (Cyd) and at $+1.60 \mathrm{~V}$ to the oxidation of uracil residue (Urd) in the RNA molecule. Peaks were identified by comparison with the differential pulse voltammograms for the polyhomoribonucleotide solutions (Figure 4) and based on previous results. ${ }^{35}$

The different peak current values obtained for each base are due to their different relative content in the RNA sequence and also reflect the different accessibilities of individual bases to the electrode surface, due to their involvement in secondary and tertiary structure interactions. Presumably, ribozyme folding will be influenced by the interaction with a charged electrode and thus may differ from the behavior in bulk solution. ${ }^{13}$

The influence of the folding architecture on the voltammetric response of comparable RNA molecules is shown in Figure 5, where a differential pulse voltammogram obtained for 38-mer RNA is superimposed on that obtained for the 49-mer RNA. The four peaks are detected at almost equal potentials, but the currents 


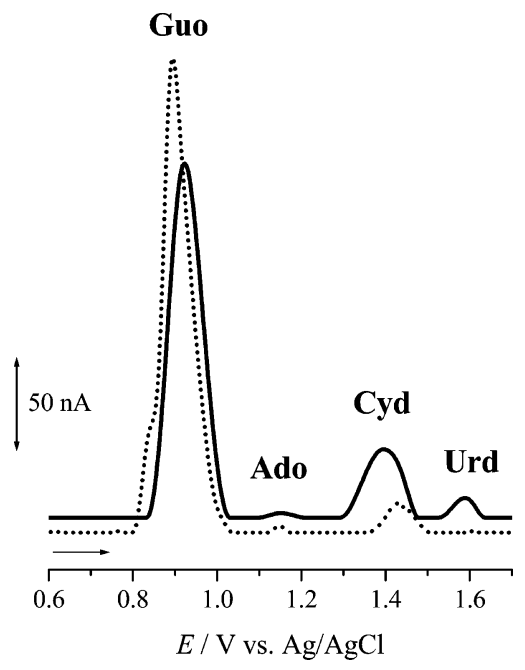

Figure 5. Baseline-corrected differential pulse voltammograms obtained for $50 \mu \mathrm{g} \mathrm{mL}^{-1} 49-\mathrm{mer}(-)$ and 38-mer (•••) RNA in pH 7.1, $0.05 \mathrm{M}$ phosphate buffer supporting electrolyte. Pulse amplitude 50 $\mathrm{mV}$, pulse width $70 \mathrm{~ms}$, and scan rate $5 \mathrm{mV} \mathrm{s}^{-1}$.

are different. The decrease of Ado, Cyd, and Urd peaks and the increase of the Guo peak in 49-mer RNA reflect a different secondary (and perhaps even tertiary) structure of the RNA molecules owing to different chain length and base composition (Figure 1). The electrochemical results can be explained by different exposure of the base residues due to the conformation of the molecule onto the electrode surface in order to enable oxidation. In fact, the 38-mer RNA presents a tail with Gua residues that are not paired and consequently are more exposed to oxidation. In the 49-mer RNA, these Gua residues are in helix I and loop 1, Figure 1, causing a different secondary structure. The voltammetric results show that Cyd residues in the 49-mer RNA are more exposed to the electrode surface, and the oxidation peak is shifted to less positive potentials, which reflects the fact that their oxidation is somehow facilitated. The same happens for the Urd oxidation peak that is almost undetectable in the voltammogram of the 38-mer RNA but appears well defined in the 49-mer RNA voltammogram. These results show how voltammetry can be used to detect different ribonucleic acids secondary structures.

Effect of $\mathrm{Mg}^{2+}$ and $\mathrm{Pb}^{2+}$ on the Adsorption of 49-Mer Diels-Alderase Ribozyme. Metal ions play a crucial role in RNA function. The ability to adopt a specific tertiary structure, and the stabilization or destabilization of that structure, depend on specific and nonspecific interactions with certain classes of metal ions.

In the crystal structure of the 49-mer Diels-Alderase ribozyme molecule, there are eight hydrated $\mathrm{Mg}^{2+}$ cations that participate in the stabilization of the RNA structure (Figure 1c), and the divalent cation dependence of the imino proton NMR spectra of the ribozyme-product complex demonstrated that a minimum of two $\mathrm{Mg}^{2+}$ cations are required for the formation of the folded 3-D structure. ${ }^{14}$

Therefore, the influence of $\mathrm{Mg}^{2+}$ on the 49-mer ribozyme's adsorption onto $\mathrm{HOPG}$ was evaluated. $\mathrm{MgCl}_{2}$ concentrations of $5 \mu \mathrm{M}$ and $20 \mathrm{mM}$ were studied. Figure 6 presents AFM images in air of 49-mer ribozymes adsorbed in the presence of $\mathrm{Mg}^{2+}$ cations. At $5 \mu \mathrm{M} \mathrm{Mg}^{2+}$ (Figure 6a), the images did not show significant differences compared to ribozymes adsorbed in the absence of $\mathrm{Mg}^{2+}$ (Figure 3a). Increasing the concentration of $\mathrm{Mg}^{2+}$
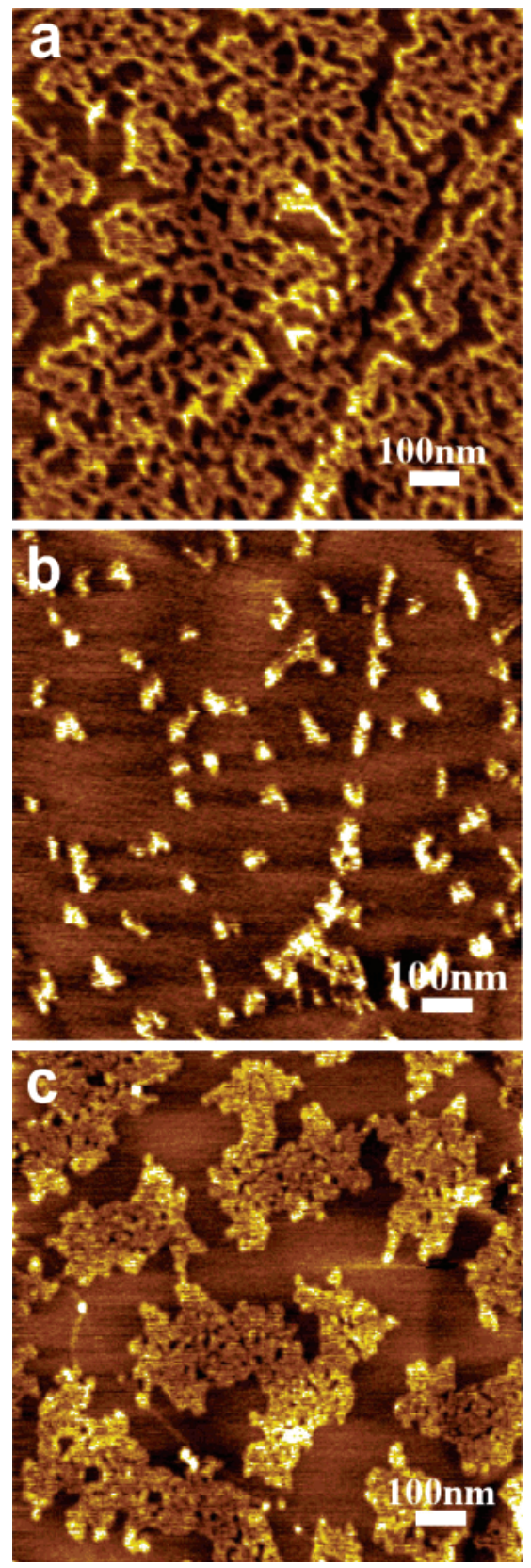

Figure 6. AFM topographical images in air of 49-mer ribozyme molecules, immobilized by free adsorption during 3 min onto HOPG, from the follwoing: (a, c) 5 and (b) $1 \mu \mathrm{g} \mathrm{mL}^{-1}$ ribozymes in $\mathrm{pH} 7.1$, $0.05 \mathrm{M}$ phosphate buffer, after addition of $\mathrm{MgCl}_{2}$ in final concentration of (a) $5 \mu \mathrm{M}$ and (b, c) $20 \mathrm{mM} \mathrm{MgCl}_{2}$.

to $20 \mathrm{mM}$, the adsorption onto HOPG was significantly reduced for both 1 (Figure $6 \mathrm{~b}$ ) and $5 \mu \mathrm{g} \mathrm{mL} \mathrm{m}^{-1} 49$-mer ribozyme (Figure $6 c)$.

For the preparation of the ribozyme samples, the electrodes are always rinsed with Milli- $\mathrm{Q}$ water prior to drying and $\mathrm{AFM}$ imaging, in order to remove weakly bound RNA molecules to the surface and buffer salts that may interfere with the AFM imaging, causing artifacts and resulting in misleading interpretations. Since the $\mathrm{Mg}^{2+}$ ions are not tightly bound, it may be assumed that they can be simply washed away by rinsing the sample, and the tertiary structure (and maybe even the secondary) might break down. However, since for such small molecules we cannot distinguish by AFM between different morphological conformations of the 

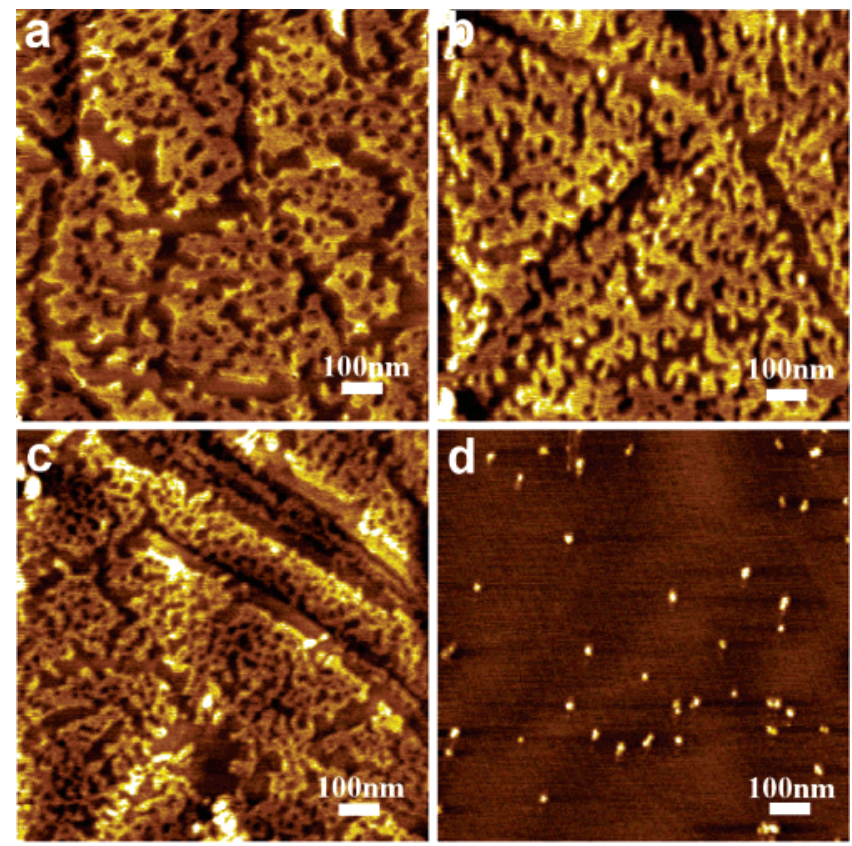

Figure 7. AFM topographical images in air of 49-mer ribozyme molecules, immobilized by free adsorption during 3 min onto HOPG, from the following: (a) $5 \mu \mathrm{g} \mathrm{mL}-1$ ribozymes in $\mathrm{pH} 7.1,0.05 \mathrm{M}$ phosphate buffer, after addition of $\mathrm{Pb}\left(\mathrm{NO}_{3}\right)_{2}$ in final concentration of (a) $5 \mu \mathrm{M}$, (b) $0.5 \mathrm{mM}$, (c) $2.7 \mathrm{mM}$, and (d) $20 \mathrm{mM}$.

ribozymes, the focus of this investigation was on the differences in surface coverage with RNA molecules. The decrease in surface coverage by the ribozymes incubated with $\mathrm{Mg}^{2+}$ is therefore likely due to the fact that the molecules adopt different conformations in solution, which can prevent a strong attachment of the molecules on the surface during the 3 min free adsorption. The strong stabilization of the RNA tertiary structure in the presence of $\mathrm{Mg}^{2+}$ in a very compact, stable, and tightly folded conformation protects the hydrophobic bases interacting with the HOPG surface. High concentrations of $\mathrm{Mg}^{2+}$ may also offer increased protection for the unfolding of the ribozymes during adsorption on $\mathrm{HOPG}$, since the hydrophobic surfaces may also induce opening of the secondary structure of nucleic acids. ${ }^{42}$

AFM was also used to determine the cleavage of ribozyme molecules in the presence of $\mathrm{Pb}^{2+}$ cations and in order to see any possible implications on the adsorption of ribozyme molecules onto HOPG.

$\mathrm{Pb}\left(\mathrm{NO}_{3}\right)_{2}$ concentrations of $5 \mu \mathrm{M}, 0.5 \mathrm{mM}, 2.7 \mathrm{mM}$, and 20 $\mathrm{mM}$ were studied in $0.05 \mathrm{M} \mathrm{pH} 7$ phosphate buffer solutions after $1 \mathrm{~h}$ incubation time. For small concentrations of $5 \mu \mathrm{M}-0.5 \mathrm{mM}$, a slight increase of the surface coverage was observed (Figure $7 \mathrm{a}$ and $\mathrm{b}$ ). A further increase in $\mathrm{Pb}^{2+}$ concentration leads to decreasing surface coverage (Figure 7c). For very high concentrations of $\mathrm{Pb}^{2+}$ almost no adsorption was observed onto HOPG, except for a few aggregates adsorbed preferentially near the HOPG step edges (Figure 7d). The last image was obtained with the supernatant of the solution, since the addition of such a high concentration of $\mathrm{Pb}^{2+}$ ions induced an almost complete precipitation of the molecules.

However, $\mathrm{Pb}\left(\mathrm{NO}_{3}\right)_{2}$ also interacts with the phosphate buffer, and its reaction product $\mathrm{Pb}_{3}(\mathrm{PO} 4)_{2}$ has a high solubility product

(42) Belotserkovskii, B. P.; Johnston, B. H. Anal. Biochem. 1997, 251, 251262.
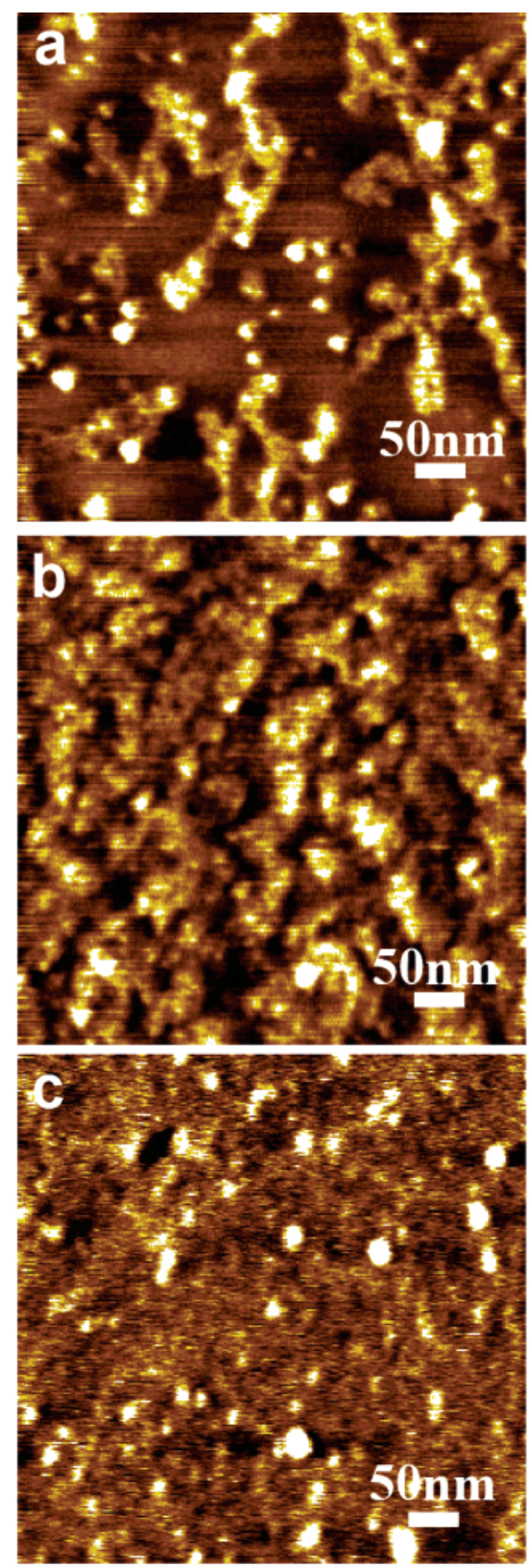

Figure 8. AFM topographical images in air of 49-mer ribozyme molecules, immobilized by free adsorption during 3 min onto HOPG, from the following: (a) $3 \mu \mathrm{g} \mathrm{mL}-1$ ribozymes in Millipore Milli-Q water, and after addition of $\mathrm{Pb}\left(\mathrm{NO}_{3}\right)_{2}$ in final concentration of (b) 2.7 and (c) $20 \mathrm{mM}$.

constant, precipitates very rapidly in solution dragging the small ribozyme fragments, and being most likely the cause for the decrease of surface coverage. In order to distinguish the true effect of the presence of $\mathrm{Pb}^{2+}$ cations on the adsorption of ribozymes onto HOPG, solutions of $3 \mu \mathrm{g} \mathrm{mL}{ }^{-1}$ ribozymes in Millipore Milli-Q water were used (Figure 8a). Panels b and $\mathrm{c}$ in Figure 8 present AFM images in air of 49-mer ribozymes adsorbed in the presence of $\mathrm{Pb}^{2+}$ cations. For both $2.7 \mathrm{mM}$ (Figure $8 \mathrm{~b}$ ) and $20 \mathrm{mM}$ (Figure 8c) final concentrations of $\mathrm{Pb}\left(\mathrm{NO}_{3}\right)_{2}$ in solution and $30 \mathrm{~min}$ incubation, a strong increase of the surface coverage was observed in the AFM images.

Lead ions tend to bind nucleic acids more strongly than $\mathrm{Mg}^{2+}$. $\mathrm{Pb}^{2+}$ is known to catalyze specific cleavage of the hexanucleotide stretch $\mathrm{A}_{15} \mathrm{~A}_{16} \mathrm{U}_{17} \mathrm{~A}_{18} \mathrm{C}_{19} \mathrm{U}_{20}$ present on the longer side of the 


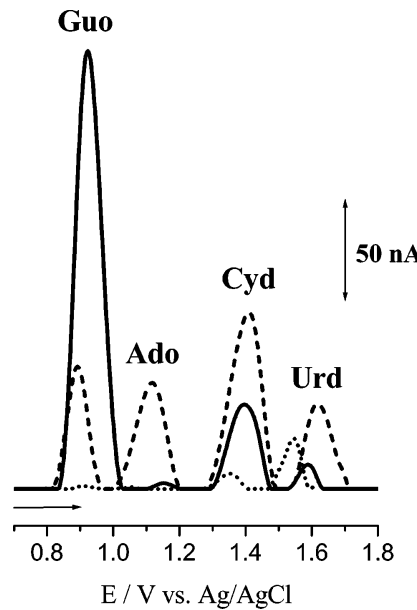

Figure 9. Baseline-corrected differential pulse voltammograms for (-) $50 \mu \mathrm{g} \mathrm{mL}^{-1}$ of a 49 -mer ribozyme in $\mathrm{pH} 7.1,0.05 \mathrm{M}$ phosphate buffer supporting electrolyte, with (- - ) $20 \mu \mathrm{M} \mathrm{Pb}^{2+}$ or (•.•) 150 $\mu \mathrm{M} \mathrm{Mg}^{2+}$. Pulse amplitude $50 \mathrm{mV}$, pulse width $70 \mathrm{~ms}$, and scan rate $5 \mathrm{mV} \mathrm{s}^{-1}$.

asymmetric internal loop of the molecule. ${ }^{13} \mathrm{~Pb}^{2+}$-induced hydrolysis occurs at positions $\mathrm{U}_{17}$ and $\mathrm{C}_{19}$ and is slightly less effective at $A_{15}$ and $A_{16}$ (Figure 1), and due to the cleavage, smaller RNA fragments are formed. Therefore, the observed enhancement of the adsorption onto HOPG is explained by the closer contact between the electrode and the hydrophobic bases of the ribozymes and RNA fragments, free bases that cease to be protected by the complex ribozyme structure.

Incubation of the 49-mer RNA with $\mathrm{Mg}^{2+}$ or $\mathrm{Pb}^{2+}$ for 30 min caused changes in the differential pulse (Figure 5). A decrease of all four current peaks was found after incubation of the RNA with $\mathrm{Mg}^{2+}$ (Figure 9). However, an increase of Ado, Cyd, and Urd current peaks was observed when the 49-mer RNA was incubated with $\mathrm{Pb}^{2+}$ (Figure 9), an interesting coincidence with the observation that $\mathrm{Pb}^{2+}$ cleavage occurs preferentially at the $\mathrm{A}_{15}, \mathrm{~A}_{16}, \mathrm{C}_{19}$, and $\mathrm{U}_{17}$ positions. This increased current may be explained by the increased accessibility and exposure of the bases as the result of chain cleavage. Although the peak attributed to Guo oxidation decreased in the presence of $\mathrm{Pb}^{2+}$, it was still higher than in the presence of $\mathrm{Mg}^{2+}$. The observed shift in the Urd oxidation peak potential is explained by the amount of base residues that undergo oxidation on the electrode surface.

The modulatory effect of a fixed concentration of one divalent cation on the variation of the Cyd current peak with the concentration of the other metal ion is shown in Figure 10. This peak was chosen for analysis since it showed the best reproducibility among all signals.

To study the influence of the cations, a solution of $50 \mu \mathrm{g} \mathrm{mL}-1$ 49-mer RNA in $0.05 \mathrm{M}$ phosphate buffer $\mathrm{pH} 7.1$ was incubated for $30 \mathrm{~min}$ with increasing concentrations of each cation in the presence and absence of a constant concentration of the other cation (100 $\mu \mathrm{M} \mathrm{Mg}^{2+}$ (Figure 10a), or $50 \mu \mathrm{M} \mathrm{Pb}^{2+}$ (Figure 10b)).

The effect of $\mathrm{Pb}^{2+}$ concentration on the Cyd peak is shown in Figure 10a. The Cyd peak was found to increase linearly up to a concentration of $50 \mu \mathrm{M} \mathrm{Pb}^{2+}$, after which it diminishes (Figure 10a, full circles). This effect was found to be shifted to a lower concentration of $30 \mu \mathrm{M} \mathrm{Pb}^{2+}$ for RNA solutions previously incubated with $100 \mu \mathrm{M} \mathrm{Mg}^{2+}$ (Figure 10a, full squares). In both a

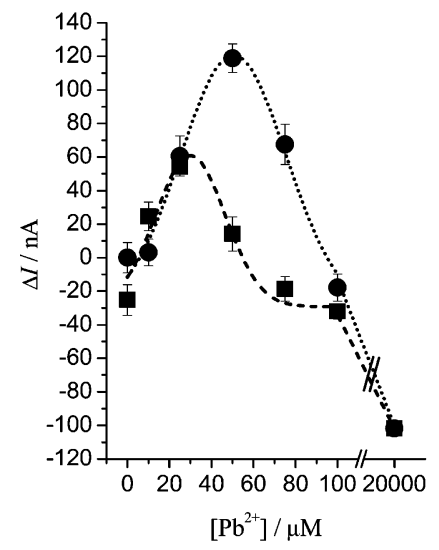

b

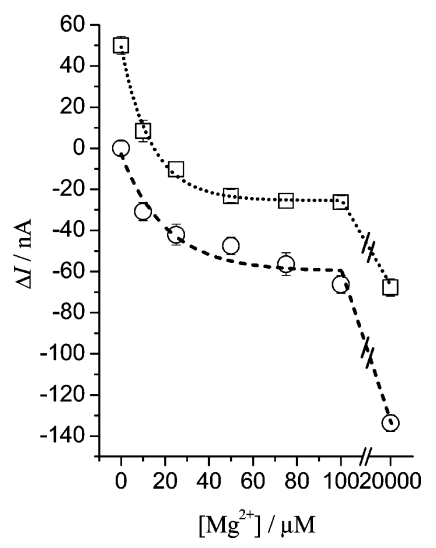

Figure 10. Effect of $\mathrm{Pb}^{2+}$ and $\mathrm{Mg}^{2+}$ concentration on the cytosine current peak obtained by differential pulse voltammetry for $50 \mu \mathrm{g} \mathrm{mL}^{-1}$ 49-mer ribozyme in $\mathrm{pH} 7.1,0.05 \mathrm{M}$ phosphate buffer supporting electrolyte: (a) $\mathrm{Pb}^{2+}$ (full circle) and $\mathrm{Pb}^{2+}+100 \mu \mathrm{M} \mathrm{Mg}^{2+}$ (full square); (b) $\mathrm{Mg}^{2+}$ (open circle) and $\mathrm{Mg}^{2+}+50 \mu \mathrm{M} \mathrm{Pb}^{2+}$ (open square). The values of $\Delta /$ are in relation to the Cyd current peak obtained for $0 \mu \mathrm{M}$ $\mathrm{Pb}^{2+}$ (a) and $0 \mu \mathrm{M} \mathrm{Mg}^{2+}$ (b). See text for other experimental details. Each error bar represents the standard deviation obtained for 3 independent experiments.

cases, no current peaks were observed in the voltammograms when concentrations of $\mathrm{Pb}^{2+}$ higher than $1 \mathrm{mM}$ were used.

The effect of $\mathrm{Mg}^{2+}$ concentration on the Cyd current peak is shown in Figure 10b. The Cyd peak decreases sharply with increasing $\mathrm{Mg}^{2+}$ concentration, reaching a constant value above $30 \mu \mathrm{M} \mathrm{Mg}^{2+}$ (Figure 10b). For RNA solutions previously incubated with $50 \mu \mathrm{M} \mathrm{Pb}^{2+}$ (Figure 10b), the Cyd peak was found to decrease following a first-order exponential decay; it is, however, always higher than in the absence of $\mathrm{Pb}^{2+}$. Peaks were still observed in the voltammograms even for a $20 \mathrm{mM} \mathrm{Mg}{ }^{2+}$ concentration.

\section{CONCLUSIONS}

The AFM results indicate that 49-mer Diels-Alderase ribozymes adsorb freely onto HOPG and that the molecules organize in largescale, two-dimensional networks that cover the entire electrode uniformly. The 49-mer ribozymes adsorb less than truncated 38-mer RNA sequences, due to the formation of a different secondary structure in solution, with the hydrophobic bases of the ribozymes being more protected and unable to undergo strong hydrophobic interactions with the hydrophobic carbon electrode. The adsorption of ribozymes was reduced after addition of $\mathrm{Mg}^{2+}$ in solution, which results in a lower coverage of the electrode surface. This result reflects the compact tertiary structure of the 49-mer ribozyme in the presence of $\mathrm{Mg}^{2+}$ ions. By contrast, $\mathrm{Pb}^{2+}$ enhanced the adsorption of the Diels-Alderase ribozyme, likely according to the formation of less structured small RNA fragments in solution.

The major findings of the AFM imaging study are in agreement with the voltammetric experiments, which quantify those nucleobases of a folded RNA that can be oxidized on the glassy carbon electrode surface. The base oxidation peaks confirmed the integrity of both Diels-Alderase ribozyme molecules studied. The effects of increasing concentrations of $\mathrm{Mg}^{2+}$ and $\mathrm{Pb}^{2+}$ ions on the 49-mer ribozyme secondary and tertiary structures was followed by voltammetry, and the results are in agreement with the AFM 
experiments. Thus, these techniques might provide an attractive method to monitor structural changes associated with RNA folding, binding, and catalysis.

\section{ACKNOWLEDGMENT}

Financial support from Fundação para a Ciência Tecnologia (FCT) Post-Doc Grant SFRH /BPD/14425/2003 (A.-M.C.P.), Ph.D. Grant PRAXIS XXI/BD/6134/2001 (J.A.P.P.), POCTI (cofinanced by the European Community Fund FEDER), ICEMS
(Research Unit 103), and European Project HPRN-CT-2002-00186 are gratefully acknowledged. A.J. acknowledges support from the Deutsche Forschungsgemeinschaft and the Human Frontier Science Program.

Received for review June 7, 2006. Accepted September $21,2006$.

AC061040+ 